\title{
PENYULUHAN DAN CARA PEMBUATAN HAND SANITIZER \\ UNTUK MASYARAKAT DALAM COVID-19 \\ DI KELURAHAN PISANG CANDI KOTA MALANG
}

Celsa Evansi ${ }^{1}$, Maria Sabarina Lato Lada ${ }^{2}$, Yasinta Funan ${ }^{3}$, Desi Asrini Loda Nangi ${ }^{4}$, Timbul Yuwono ${ }^{5}$ Universitas Kanjuruhan Malang ${ }^{1,2,3,4,5}$

Email:

1Celsaet@gmail.com,2mariaratolada27@gmail.com,3yasintafunan13@gmail.com,4asrinidesi5@ gmail.com, ${ }^{5}$ timbulyuwono@unikama.ac.id

Abstract : Most of the people in Pisang Village, Candi Malang have daily activities, besides carrying out social activities limited to village organization groups. Judging from the enthusiasm to get community skills in this village, it is hoped that they can be given skills to support increased family income through Community Partnership Program (PKM) activities, for example by training or counseling on making hand sanitizers which are very popular and needed today, especially for the middle and upper economic class people in covid-19, namely as a hand sanitizer that is healthy and fresh while preventing the covid-19 virus. This product can be marketed through grocery stores and supermarkets, so it is very good to be developed into a superior product. Making hand sanitizer products is very easy, using simple tools and at a fairly low cost. With various ingredients such as Alcohol, Glycerol, $\mathrm{H} 2 \mathrm{O} 2$, and Aquades. Based on this, it is deemed necessary to respond to this situation, by providing counseling and training on how to manufacture hand sanitizer products with natural ingredients, good packaging and marketing methods for the community in kelurahan Pisang Candi Malang, so as to produce hand-made products that have homemade results. selling value, so as to increase income, which in turn get a more prosperous family life.

Keywords : Hand Santizer According to WHO Standards, Kelurahan Pisang Candi

\footnotetext{
Abstrak : Sebagian besar masyarakat di Kelurahan Pisang Candi Malang memiliki kegiatan sehari-hari, disamping itu melakukan aktivitas sosial terbatas pada kelompok organisasi Pemberdayaan Kesejahteraan Keluarga. Dilihat dari peminatan untuk mendapatkan keterampilan masyarakat di desa ini cukup antusias, besar harapan mereka dapat diberi keterampilan untuk mendukung peningkatan pendapatan keluarga melalui kegiatan Program Kemitraan Masyarakat (PKM), misalnya dengan pelatihan atau penyuluhan pembuatan Hand Sanitizeryang sangat
} 
banyak digemari dan dibutuhkan saat ini terutama bagi masyarakat kelas ekonomi menengah ke atas dalam covid-19, yaitu sebagai mempembersih tangan yang sehat dan segar sekaligus dapat membunuh dari virus covid-19. Produk ini dapat dipasarkan melalui toko keperluan sehari-hari dan swalayan, sehingga sangat bagus untuk dikembangkan menjadi produk unggulan. Pembuatan produk Hand Sanitizerini sangat mudah, menggunakan alat yang sederhana dan dengan biaya yang cukup murah. Dengan berbagai bahan seperti Alkohol, Glycerol, H2 O2, dan Aquades. Berdasarkan hal tersebut, dipandang perlu untuk menyikapi situasi ini, dengan cara diberikan penyuluhan dan pelatihan cara-cara pembuatan produk Hand Sanitizer bahan kimiawi, cara pengemasan yang baik dan cara pemasarannya bagi masyarakat dikelurahan Pisang Candi Malang, sehingga menghasilkan produk Hand Sanitizerhasil buatan sendiri mempunyai nilai jual, sehingga dapat meningkatkan penghasilan, yang pada akhirnya mendapatkan hidup keluarga yang lebih sejahtera.

Kata kunci : Hand Santizer menurut standar WHO, Di Kelurahan Pisang Candi. 


\section{PENDAHULUHAN}

Semua masyarakat sekarang ini sedang panik karena virus corona sedang tersebar di Indonesia. Mudahnya penyebaran virus ini membuat masyarakat menggunakan masker sebagai cara berjaga-jaga, menggunakan sarung tangan dan pembersih tangan setiap hari (Saadat dkk., 2020). Saat ini harus menjaga kebersihan dengan rajin mencuci tangan dengan air dan sabun untuk mencegah penularan covid-19. Untuk pembersih tangan yang mangandung alkohol adalah pilihan yang terbaik setelah mencuci tangan dengan sabun. Menggunakan pembersih tangan yang mengandung alkohol dapat mematikan virus yang menempel di tangan manusia. Dengan munculnya virus corona ini adanya persediaan hand sanitizer di toko-toko swalayan saat ini lagi menipis karena semua masyarakat sedang membutuhkan hand sanitizer untuk mencegah covid-19.

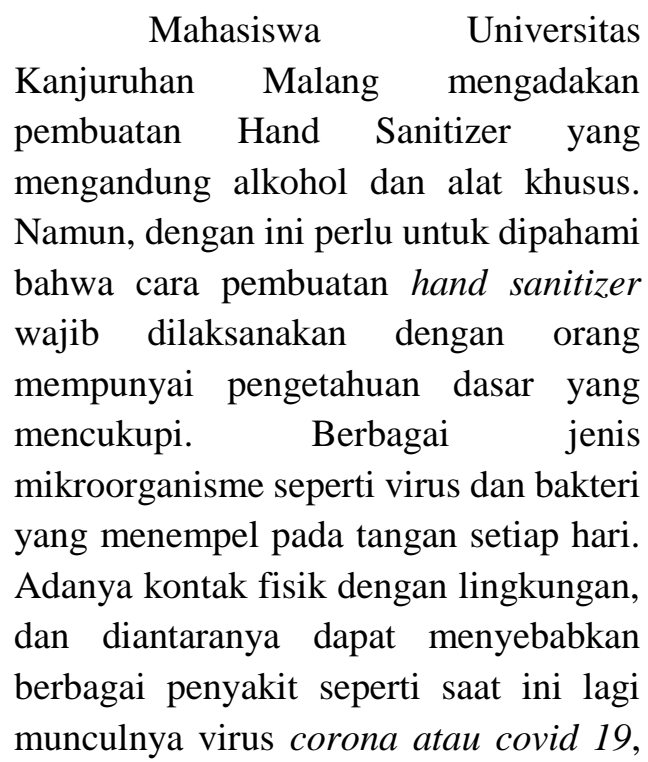

virus yang sangat berbahaya akan mematikan umat manusia jika tidak tertolong atau tidak dicegah dengan dari kesadaran kita sendiri harus waspada di luar rumah. Seperti kita harus memakai masker, menggunakan hand sanitizer, berjauhan dengan orang lain dengan jarak $1 \mathrm{~m}$, dll. Untuk itu mikroorganisme ini perlu dimusnahkan atau dicegah penyebarannya. Cara yang paling mudah adalah dengan cara membersihkan tangan menggunakan sabun dan air yang mengalir. Jika air bersih tidak tersedia, dapat juga digunakan persediaan pembersih tangan berbasis alkohol atau mengandung anti bakteri yang dikenal dengan Hand Sanitizer (Wahyono, 2010).

Pembersih tangan menggunakan bahan antiseptik dikenal sejak abad 19 . Menurut (Wahyono, 2010) Perkembangan masyarakat saat ini terutama yang berdomisili di daerah perkotaan, menuntut manusia dengan berbagai kesibukan untuk bergerak cepat dan menggunakan waktu seefisien mungkin. Ketentuan zaman yang demikian mengharuskan manusia untuk menjaga kesehatannya agar terhindar dari penyakit terutama saat ini adanya covid-19.

Pemakaian antiseptik tidak hanya dalam bentuk gel saja tetapi bentuk cair pun juga ada saat ini yang lebih populer dengan nama Hand Sanitizerdi kalangan masyarakat ekonomi sudah menjadi suatu gaya hidup. Berbagai produk Hand Sanitizer dapat di temukan di toko-toko swalayan dengan cara pemakaian yang cukup sederhana dan cepat yaitu dengan diteteskan pada telapak tangan, 
kemudian diratakan pada permukaan tangan. Namun biasanya banyak mengandung alkohol dan antiseptik berupa bahan kimia sintetis yang harganya relatif mahal dan sering menimbul masalah kesehatan kulit, misalnya kulit menjadi kering (terjadi penurunan kelembapan kulit normal) (Retnosari, 2007). Oleh karena itu perlu dicari antiseptik dari bahan alam yang relatif lebih murah, aman, efektif, dan mudah didapat, salah satu contohnya adalah Glycerol, H2O2, dan Aquades.

\section{Berdasarkan Mahmood dkk} (2020) WHO merekomendasikan pembersih tangan berbasis alkohol untuk kebersihan tangan yang sering digunakan, yang terutama terbuat dari etanol, isopropil alkohol, hidrogen peroksida kombinasi yang berbeda. Hand sanitizer efektif digunakan ketika jauh dari tempat cuci tangan, kesulitan mencari air bersih, sedang bepergian (Srikartika, Suharti, \& Anas, 2016). Hand sanitizer cukup efektif membunuh kuman dan mencegah bertambahnya mikroorganisme pada permukaan tubuh (Desiyanto \& Djannah, 2013).

Para pelaksana pengabdian kepada masyarakat penting untuk melakukan komunikasi, komunikasi dan edukasi untuk meningkatkan pengetahuan dan pemahaman masyarakat. Hal juga disampaikan Mardianti dkk (2020) promosi kesehatan digunakan melakukan komunikasi, edukasi dan informasi pada masyarakat digunakan penyebaran informasi dapat meningkatkan pengetahuan dan pemahaman masyarakat tentang penggunaan obat yang benar dan rasional
Pembuatan Hand Sanitizer dalam bentuk sediaan cair yang hiegenis dari bahan kimiawitidak sulit dan tidak membutuhkan biaya yang mahal dengan bahan dan peralatan yang dibutuhkan sangat sederhana, sehingga dapat diproduksi dan mempunyai nilai ekonomi, di samping itu yang dibutuhkan untuk keperluan pembuatan Hand Sanitizeri ni dapat dibudidayakan di lingkungan masyarakat. Berdasarkan hal tersebut di atas, dipandang perlu untuk menyikapi situasi ini, dengan memberi penyuluhan pembuatan Hand Sanitizer bagi masyarakat di kelurahan Pisang Candi Kota Malang

\section{URGENSI DAN RASIONALISASI PENGABDIAN}

Setelah mengikuti bimbingan dan pelatihan diharapkan nantinya masyarakat di Kelurahan Pisang Candi Kota Malang, akan mempunyai keterampilan membuat sediaan kegiatan pembuatan Hand Sanitizertanpa bahan kimia yang mudah didapatkan di sekitar lingkungan tempat tinggal, dan telah terbukti dapat membunuh dan mencegah virus corona atau covid-19 Hand sanitizer sangat berguna untuk menjaga kebersihan dan kesehatan, dan digemari penggunaannya oleh masyarakat terutama yang mempunyai tingkat ekonomi menengah ke atas, Sehingga besar harapan produk ini dapat dipasarkannya, ke kios-kios, swalayan, toko-toko keperluan sehari-hari, atau ke rumah makan

\section{METODE PELAKSANAAN}

Langkah-langkah kegiatan penyuluhan dapat dilakukan oleh Dosen pengajar dan mahasiswa KKN di Universitas Kanjuruhan Malang dengan 
cara memanggil dan mengumpulkan masyarakat yang tergabung di dalam kelompok Ibu-ibu PKK di ruangan pertemuan atau aula balai RW Pisang Candi untuk mengikuti bimbingan dan pelatihan pembuatan sediaan hand sanitizer dari bahan kimiawi telah terbukti dapat membunuh kuman, dan virus.Misalnya Alkohol, Glycerol, H2 O2, dan Aquades

Dengan langkah-langkah : Memberi penjelasan kegunaan dan keunggulan sediaan Hand Sanitizeryang terbuat dari bahan alami. Menjelaskan cara-cara pembuatan sediaan hand sanitizer menggunakan alat-alat yang murah dan sederhana sesuai yang dinginkan dan digemari oleh masyarakat terutama kalangan ekonomi menengah ke atas. Membimbing langsung masyarakat tersebut untuk membuat sediaan hand sanitizer dan diperoleh hasil berupa sediaan Hand Sanitizer tangan yang higenis, mempunyai khasiat anti kuman. Cara Pembuatan Hand Sanitizer dengan berbagai bahan kimia sebagai anti kuman dan virus.

\section{Bahan dasar Hand sanitizer}

1. Alkohol $96 \%$

2. Glycerol $98 \%$

3. $\mathrm{H} 2 \mathrm{O} 23 \%$

4. Aquades

\section{Cara Pembuatan Hand Sanitizer untuk 1 liter}

Menyediakan Alkohol 1.000 mili literter lebih dahulu, dimasukan $\mathrm{H} 2 \mathrm{O} 2$ sebanyak 50 mililiter, Glicerol 17.8 mililiter dan Aquades 132.2 mililiter. Untuk pemakainnya menunggu selama satu hari baru bisa siap dipakai.
Untuk hasil akhir nya adalah:

1. Alkohol $80 \%$

2. Glycerol 1,45\%

3. $\mathrm{H} 2 \mathrm{O} 20,125 \%$

\section{HASIL DAN PEMBAHASAN}

Semua masyarakat sekarang ini sedang panik karena virus corona sedang tersebar di Indonesia. Saat ini harus menjaga kebersihan dengan rajin mencuci tangan dengan air dan sabun untuk mencegah penularan covid-19. Untuk pembersih tangan yang mangandung alkohol adalah pilihan yang terbaik setelah mencuci tangan dengan sabun. Menggunakan pembersih tangan yang mengandung alkohol dapat mematikan virus yang menempel di tangan manusia. Dengan munculnya virus corona ini adanya persediaan hand sanitizer di toko-toko swalayan saat ini lagi menipis karena semua masyarakat sedang membutuhkan hand sanitizer untuk mencegah covid-19

Mahasiswa Universitas Kanjuruhan Malang mengadakan pembuatan Hand Sanitizer yang mengandung alkohol dan alat khusus. Namun, dengan ini perlu untuk dipahami bahwa cara pembuatan hand sanitizer wajib dilaksanakan dengan orang mempunyai pengetahuan dasar yang mencukupi. Berbagai jenis mikroorganisme seperti virus dan bakteri yang menempel pada tangan setiap hari.Adanya kontak fisik dengan lingkungan, dan diantaranya dapat menyebabkan/menimbulkan berbagai penyakit seperti saat ini lagi munculnya virus corona atau covid 19, virus yang sangat berbahaya akan mematikan umat manusia jika tidak tertolong atau tidak dicegah dengan dari kesadaran kita sendiri harus waspada di luar rumah. 
Seperti kita harus memakai masker, menggunakan hand sanitizer, berjauhan dengan orang lain dengan jarak $1 \mathrm{~m}$, dll. Pembersih tangan yang mempunyai manfaat untuk anti bakteri dalam menghambat hingga membunuh bakteri merupakan definisi dari Hand Sanitizer (Retnosari dan Isdiartuti, 2006). Menurut Diana (2012) terdapat dua macam hand sanitizer yaitu hand sanitizer gel dan spray. Hand Sanitizerspray adalah pembersih tangan berbentuk spray yang digunakan untuk membersihkan atau menghilangkan kuman pada tangan, yang mengandung bahan glycerol $1,45 \%$ dan alkohol 80\%. Penelitian Diana (2012) membuktikan, bahwa Hand Sanitizeryang berbentuk spray lebih efektif dibandingkan dengan Hand Sanitizer berbentukgel dalam menghilangkan virusdan bakteri pada tangan . kegiatan pembuatan hand sanitizer. Hand sanitizer merupakan suatu produk sediaan cair, produk ini berfungsi sebagai pemberi aroma yang sehat dan segar pada tangan sekaligus dapat membunuh kuman, yang saat ini banyak digemari oleh masyarakat untuk pemeliharaan kebersihan dan kesehatan tangan, serta mencegah pencemaran kuman pada saat hendak konsumsi makanan. sehingga sangat potensial untuk dikembangkan menjadi suatu produk. Melihat situasi ini masih besar harapan bahwa taraf kehidupan masyarakat di Kelurahan ini dapat ditingkatkan melalui kegiatan masyarakat yang dapat membantu melindungi sesama keluarga dari covid19, salah satu caranya dengan Penggunaan Hand Sanitizer yang berlebihan tidak baik untuk kesehatan kulit dan setelah pemakain Hand Sanitizer berulang-ulang harus tetap cuci tangan. Hal sesuai dengan pendapat Beiu dkk (2020) Efek dermatologis yang merugikan, seperti kulit kering yan dapat terjadi, terutama pada individu dengan riwayat dermatitis atopik. Kondisi kulit ini dapat ditangani dengan sempurna, dan mengoleskan pelembab segera setelah mencuci tangan atau setelah menggunakan pembersih tangan portabel adalah hal terpenting dalam mencegah perkembangan perubahan eksim di tangan

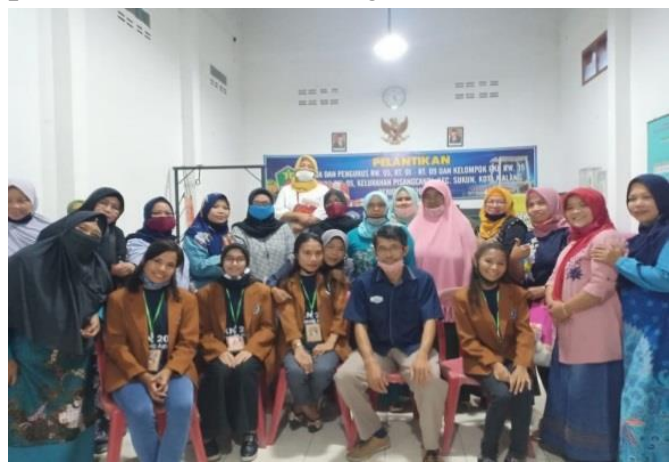

Gamar 1: bersama Ibu-ibu Pemberdayaan Kesejahteraan Keluarga atau PKK

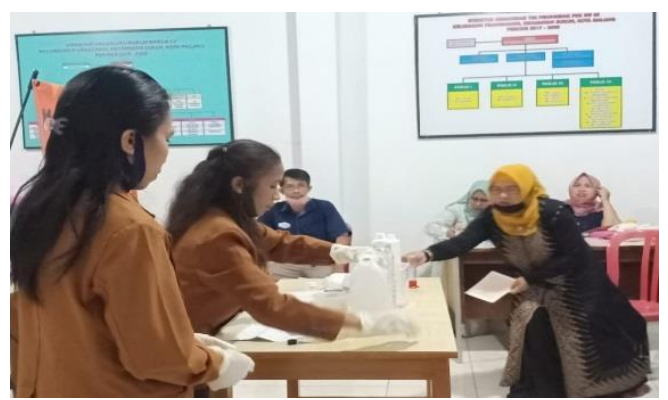

Gamabar 2: Pembuatan Hand Sanitizer bersama Ibu-ibu PKK

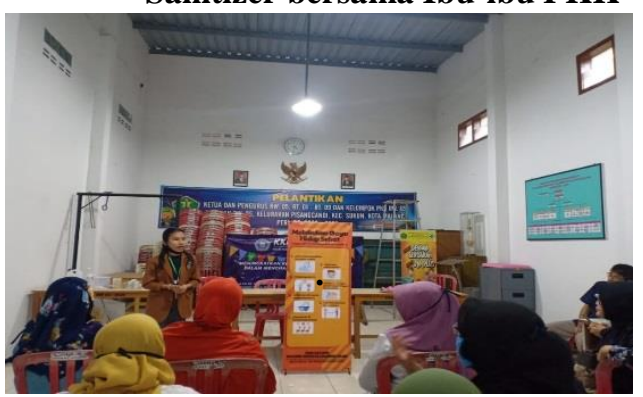

Gambar 3: Melakukan penyuluhan bersama Ibu-ibu PKK 


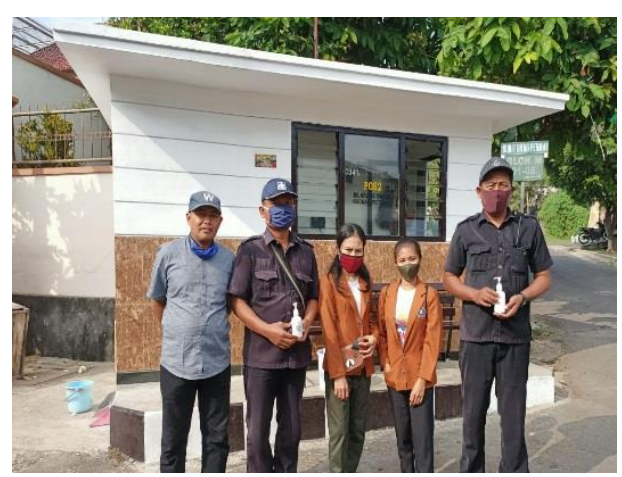

Gambar 4: Membagikan Hand Sanitizer kepada satpam-satpam

\section{SIMPULAN}

Masyarakat melakukan gaya hidup sehat merupakan bagian dari melindungi kita dari covid. Untuk hidup tetap sehat seperti dimasa pandemi seperti ini kita tetap menjaga kesehatan, agar bisa terhindar dari covid-19. Untuk itu mikro organisme ini perlu dimusnahkan atau dicegah penyebarannya. Cara yang paling mudah adalah dengan cara membersihkan tangan menggunakan sabun dan air yang mengalir. Jika air bersih tidak tersedia, dapat juga digunakan persediaan pembersih tangan berbasis alkohol atau mengandung anti bakteri yang dikenal dengan Hand Sanitizer. Pembersih tangan yang mempunyai manfaat untuk anti bakteri dalam menghambat hingga membunuh bakteri

\section{SARAN}

Untuk memperoleh keterampilan bagi masyarakat, sebaiknya diadakan bimbingan dan penyuluhan untuk pembekalan keterampilan secara rutin setiap tahun dengan bentuk produk yang berbeda, sehingga diharapkan masyarakat mempunyai keterampilan yang beraneka ragam dan dapat berwirausaha dengan berbagai produk.
Demi kelancaran kewirausahaan masyarakat tersebut, perlu dibentuk koperasi dan bantuan pemasaran produk misalnya adanya penghubung koperasi dengan swalayan-swalayan terdekat, sampai jangkauan yang semakin hari semakin meluas

\section{DAFTAR RUJUKAN}

Ditjen, P. O. M. (1985). Formularium Kosmetika Indonesia. Jakarta: Departemen Kesehatan RI. Hal, 83(85), 106-132.

Ansel, H.C. 1989. Pengantar Bentuk Sediaan Farmasi. Edisi III. Diterjemahkan Oleh Ibrahim, F. Jakarta: UI Press.

Anwar, E. (2012). Eksipien dalam Sediaan FarmasiKarakterisasi dan Aplikasi. Jakarta: $\quad P T \quad$ Dian Rakyat, 249.

Beiu, C., Mihai, M., Popa, L., Cima, L., \& Popescu, M. N. (2020). Frequent hand washing for COVID-19 prevention can cause hand dermatitis management tips. Cureus, 12(4)

Desiyanto, F. A., \& Djannah, S. N. (2013). Efektivitas Mencuci Tangan Menggunakan Cairan Pembersih Tangan Antiseptik (Hand Sanitizer) Terhadap Jumlah Angka Kuman. Jurnal Kesehatan Masyarakat (Journal of Public Health), 7(2), 7582.

https://doi.org/10.12928/kesmas.v7 i2.1041

Diana, A. (2012) pengaruh desiminasi dokter kecil tentang penggunaan hand sanitizer dan spray terhadap penurunan angka kuman tangan siswa sdn demakijo gamping 
sleman. Skripsi politekes kemenkes yogyakarta.

World Health Organization. (2005).

Guidilines for Hand Sanitizer

Formulation Design and drug

Deliveri. Singapore: Jhon Wiley and Sons.

Mahmood, A., Eqan, M., Pervez, S., Alghamdi, H. A., Tabinda, A. B., Yasar, A., ... \& Pugazhendhi, A. (2020). COVID-19 and frequent use of hand sanitizers; human health and environmental hazards by $\mathrm{V}$ GEDC0053JHJexposure

pathways. Science of The Total Environment, 742, 140561. https://doi.org/10.1016/j.scitotenv.2 020.140561

Mardiati, N., Nurrahma, I. M., \& Nazarudin, M. (2020). Promosi Kesehatan "Tanya Lima O" Di Desa Beruntung Jaya, Sungai Tiung, Cempaka, Banjarbaru, Kalimantan Selatan. Jurnal Pengabdian Masyarakat Khatulistiwa,3(1), 4145.https://doi.org/10.31932/jpmk.v3 i1.679

Saadat, S., Rawtani, D., \& Hussain, C. M. (2020). Environmental perspective of COVID-19. Science of The Total Environment, 138870. https://doi.org/10.1016/j.scitotenv.2 020.138870

Sari, R., \& Isadiartuti, D. (2006). Studi efektivitas sediaan gel antiseptik tangan ekstrak daun sirih (Piper betle Linn.). Majalah Farmasi Indonesia, 17(4), 163-169.

Srikartika, P., Suharti, N., \& Anas, E. (2016). Kemampuan Daya Hambat
Bahan Aktif Beberapa Merek Dagang Hand sanitizer terhadap Pertumbuhan Staphylococcus aureus. Jurnal Kesehatan Andalas, 5(3)540-545.

https://doi.org/10.25077/jka.v5i3.61 3

Wahyono, S., Widanarko, S., Moersidik, S. S., \& Djajadiningrat, S. T. (2012). Metabolisme Pengelolaan Sampah Organik Melalui Teknologi Komposting Di Wilayah Internal Perkotaan. Jurnal Teknologi Lingkungan, 13(2), 179-192 